\title{
Yabancılara Türkçe Öğretiminde Yunus Emre'nin Şiir ve Menkıbelerinden Yararlanma
}

\section{Using Yunus Emre's Poems and Parables in Teaching Turkish For Foreigners}

\author{
Dr. Öğr. Üyesi Umut BAŞAR (D) 1
}

\begin{abstract}
$\ddot{\mathbf{O} z}$
Yabancılara Türkçe öğretiminde kültürel bilgi paylaşımı ve özgün ders materyali kullanımı alanyazında araştırmacıların üzerinde sıklıkla durduğu konulardan biridir. Edebî eserler ise gerek kültürel bilgi barındırması gerek özgün (otantik) dil öğretim materyali sayılabilmesi açısından yabancı dil öğretiminde sıklıkla başvurulan kaynak metinler arasında yer almaktadır. Nitekim başta İngilizce olmak üzere Almanca, Fransızca gibi dünya dillerinin yabancılara öğretimde hem modern hem de klasik edebî eserlerin uzun yıllardan beri kullanıldığı bilinmektedir. Uyarlama ve seviyelendirme yoluyla edebî eserler, yabancı dil öğretiminde ders materyaline dönüştürülmektedir. Bu çerçevede çalışmanın amacı, esasen çağdaş bir şair olmayan Yunus Emre'nin şiirlerinden ve hayatına dair menkıbelerden yabancılara Türkçe öğretirken kültür aktarıcısı ve dil öğretim malzemesi olarak nasıl yararlanılabileceğini örnekleriyle göstermektir. Bu amaç doğrultusunda B1 ve B2 seviyelerinde Yunus Emre'nin şiirlerinden ve hayatı hakkındaki anlatılardan faydalanmanın, yabanıı dil öğretiminde yaşayan/kullanılan Türkçenin öğretilmesine dair ilkeyle çelişki göstermediği ortaya koyulacaktır. Bunun için çalışma, kültür aktarıcısı ve dil öğretim malzemesi olarak Yunus Emre şiirleri ve anlatıları olmak üzere iki ana başlıkta kurgulanmıştır. Bu başlıklarda teorik açıklamaların yanı sıra konuyu somutlaştırmak adına sınıf içi uygulama örneklerine de yer verilmiştir. Uygulama örnekleri iki saatlik ders planlarından oluşmaktadır. Ancak çalışmanın sınıf içi uygulama boyutu bulunmadığından örneklerin Türkçe öğretim ortamında hedef kitleyle kullanımı başka bir çalışmaya bırakılmıştır. Çalışmanın son bölümünde ise konuya dair önerilerde bulunulmuştur.
\end{abstract}

Anahtar Kelimeler: Yunus Emre, kültür aktarımı, Türkçe öğretimi, menkıbe, edebî eser

Makale Türü: Araştırma

\begin{abstract}
Sharing cultural knowledge and using original course material in teaching Turkish to foreigners is one of the topics that researchers often focus on in the field. Literary works are one of the source texts often referenced in foreign language teaching, both in terms of containing cultural knowledge and in terms of being considered authentic (authentic) language teaching material. In this context, the aim of the study is to show with examples how Yunus Emre, who is not a contemporary poet, can use his poems and life as a cultural transferor and language teaching material when teaching Turkish to foreigners. For this purpose, it will be revealed that the use of Yunus Emre's poems and narratives about his life at levels B1 and B2 does not contradict the principle of teaching the Turkish language that lives/is used in teaching foreign languages. For this purpose, the work is fictionalized in two main titles: Yunus Emre poems and narratives as a cultural transferor and language teaching material. In addition to theoretical explanations, examples of classroom practice are included in these titles to embody the subject In the last part of the study, suggestions were made on the subject.
\end{abstract}

Keywords: Yunus Emre, cultural information sharing, Turkish teaching, parable, literary work

Paper Type: Research

\footnotetext{
${ }^{1}$ Ankara Sosyal Bilimler Üniversitesi, Sosyal ve Beşeri Bilimler Fakültesi, umutbasar_35@hotmail.com

Atıf için (to cite): Başar, U. (2021). Yabancılara Türkçe öğretiminde Yunus Emre'nin şiir ve menkıbelerinden yararlanma. Afyon Kocatepe Üniversitesi Sosyal Bilimler Dergisi, 23(Yunus Emre ve Türkçe Özel Sayısı), 112-122.
} 


\section{Giriş}

Türk edebiyatının en önemli kalemlerinden biri olan Yunus Emre (1240?-1320?) eserlerini ortaya koyduğu 13. yüzyılın ikinci yarısından günümüze kadar sevilen isimlerden biri olma özelliğini yitirmemiştir. Bu sebeple onun sanat, fikirleri, şiirlerinin estetik boyutu ve dili üzerine hatırı sayılır derecede araştırmalar yapılmıştır. Öyle ki Yunus Emre’ye ilişkin çalışmalar bibliyografyalarda (Binark ve Sefercioğlu, 1970; Tatcı ve Gürelli, 1988; Can, 2016) toplanacak düzeye ulaşmıştır. Üstelik Yunus Emre, Türkiye Türkoloji'sinin dışına çıkarak yurt dışındaki araştırmacılar tarafından çeşitli incelemelere konu olduğu gibi şiirleri pek çok dile tercüme edilmiştir.

Bilindiği üzere Yunus Emre, Türkiye Türkçesinin temellerinin atılmasında etkili olan kalemlerden biridir. Yunus Emre'nin edebî dili, Türkiye Türkçesinin tarihî tasnifi açısından kökleri Eski Türkçeye kadar ulaşan Oğuzcan'ın batı kolu olarak kabul edilen Eski Anadolu Türkçesine (13 ila 15. yüzyıllar) denk gelmektedir. Bu doğrultuda Korkmaz (1973, s. 17-18) söz konusu dönemde Yunus Emre'nin Türkçe yazan birçok çağdaşı bulunsa da Oğuzcaya dayalı Anadolu Türkçesinin özgün bir yazı dili olarak kuruluşunda yüksek bir şair olarak en büyük rolü oynadığını savunmakta ve onun dilinin Oğuzcadan geçme gramer şekilleri, kelime bilgisi ve dile hâkimiyet bakımından çağdaşlarıyla kıyaslanamayacak üstünlük ve olgunlukta olduğunu yazmaktadır. "Bu dil, bugünkü Türkiye Türkçesinin 16. yüzyıla kadar sürmüş olan önceliydi" (Tezcan, 2012, s. 97). Dolayısıyla hâlihazırda 83 milyondan fazla kişinin ana/ikinci dil olarak konuştuğu ve dünyanın neredeyse her bölgesinden bireylerin yabancı dil olarak öğrendiği Türkiye Türkçesinin şekillenmesinde Yunus Emre'nin işlevi görülmektedir.

Bu çalışmada Yunus Emre'nin eserlerine yabancılara Türkçe öğretimi çerçevesinden bakılmaktadır. Nitekim Yunus Emre ile ilgili çalıșmalara bakıldığında, Türkçenin bu benzersiz şairinin dil, tarih, edebiyat, sanat, estetik ve teoloji disiplinlerinde incelendiği gözlemlenmektedir. Yunus Emre eğitim bilimlerinde nispeten daha az çalışmaya konu olmuştur. Fakat onun eserleri eğitim bilimleri çerçevesinde de irdelemeye uygundur. Örneğin Kaya (2014) tarafından Yunus Emre Divanı ana dili olarak Türkçe öğretimi açısından incelenmiştir. Araştırmacı çalışmasında, Yunus Emre Divanı'nda yer alan okuma, dinleme, konuşma ve yazma dil becerilerinin eğitimi ve geliştirilmesiyle ilgili ifadelerin tespit edilerek Yunus Emre Divanı'nın Türkçe öğretimine katkısını ortaya koymayı amaçlamıştır. Ancak ulaşılabildiği kadarıyla, Yunus Emre'nin eserleri ve hayatı yabancılara Türkçe öğretmek üzere hazırlanmış kitaplara girse de yabancılara Türkçe öğretimine dair akademik çalışmalara pek konu edilmemiştir. Dolasıyla bu çalışmada Yunus Emre'nin eserlerine yabancı dil öğretim materyali olarak bakılacak ve onun şiirleri yabancılara Türkçe öğretimi bağlamında değerlendirilecektir.

\section{1. Çalışmanın Amacı}

Bu çalışmanın amacı, esasen çağdaş bir şair olmayan Yunus Emre'nin şiirlerinden ve hayatına dair anlatılardan (menkıbe) yabancılara Türkçe öğretirken kültür taşıyıcısı, paylaşım arac1 ve dil öğretim malzemesi olarak nasıl yararlanılabileceğini örnekleriyle göstermektir. Bu amaç doğrultusunda B1 ve üzerindeki seviyelerde Yunus Emre'nin şiirlerinden ve hayat1 hakkındaki anlatılardan faydalanmanın, yabancı dil öğretiminde yaşayan/kullanılan Türkçenin öğretilmesine dair ilkeyle (Barın, 2004, s. 24) çelişki göstermediği ortaya koyulacaktır. Bunun için çalışma, kültür aktarıcısı ve dil öğretim malzemesi olarak Yunus Emre şiirleri ve anlatıları olmak üzere iki ana başlıkta kurgulanmıştır. Bu başlıklarda teorik açıklamaların yanı sıra konuyu somutlaştırmak adına sınıf içi uygulama örneklerine de yer verilmiştir. Uygulama örnekleri iki saatlik ders planlarından oluşmaktadır. Ancak çalışmanın sınıf içi uygulama boyutu bulunmadığından örneklerin Türkçe öğretim ortamında hedef kitleyle kullanımı başka bir çalışmada ele alınacaktır. Çalışmanın son bölümünde ise konuya dair önerilerde bulunulmuştur. 


\section{Kültürel Paylaşım Aracı Olarak Yunus Emre Şiir ve Menkıbeleri}

Yabanc1 dil öğretiminin kültürel boyutu önemli bir konudur. Nitekim yabanc1 dil eğitiminde son y1llarda hedef kitlenin amaç dilde etkili bir iletişim kurmasını önceleyen dil öğretim yaklaşımları gündemdedir. Dil, kültürün kendini gösterdiği canlı bir varlık olması nedeniyle dile hâkimiyetle kültüre hâkimiyet arasında anlamlı bir ilişki bulunduğu belirtilebilir. Doğru, etkili ve eksiksiz bir iletişim için amaç dilin kültürünü tanımak önemlidir. Nitekim Diller İçin Avrupa Ortak Öneriler Çerçevesi’nde (CEFR) kültürlerarasılık, çok kültürlülük, kültürel bilinç gibi kavramlara sıkça dikkat çekildiği gibi "Genel Yeterlikler" başlığı altında bağımsız bir "Sosyokültürel Bilgi”" başlığına yer verilmiştir. Burada konunun önemine "Bir dilin konuşulduğu bir toplumun ve bir topluluğun veya toplulukların kültürüyle ilgili bilgi, aslında mevcut dünya bilgisinin bir kısmını oluşturur. Fakat dil öğrenenin bu bilgilere özel olarak dikkat etmesi gerekir; çünkü özellikle de bunlar diğer bilgilere göre büyük ihtimalle öğrenenin daha önceki deneyim alanının dışında kalmış ve hatta basmakalıp düşüncelerle zedelenmiş olabilir." (Diller İçin Avrupa Ortak Öneriler Çerçevesi, 2013, s. 103) şeklinde değinilmiştir.

Yabancı dil derslerinde kültürel bilgi bazen örtük bazen de açık bir şekilde verilebilir. Kültürel bilgi dil öğretim materyallerinde bulunabilir, bulunmaması durumda öğretici kültürel bilginin kaynağı olabilir. Kültürel bilginin doğrudan veya dolaylı olarak verilmesi ya da ders içeriğine yedirip yedirilmemesi bir planlama ve tercih işidir. Ancak çoğu zaman dil öğretimiyle kültürel bilgi ve farkındalık birbirine paralel bir şekilde ilerler. Bu görüşü destekler nitelikte Akkaya (2013, s. 129) dil öğretiminin kültür aktarımıyla aynı düzlemde ilerlediğini, örneğin sözcük öğretimi yapılırken, temel dil becerileri geliştirilmeye çalışılırken aynı zamanda kültürel aktarımın da kendiliğinden yapıldığını öne sürmektedir. Dolayısıyla kültürel bilginin öğrenicilere nasıl verileceğine dair tercih ikincil bir konu olup kültürel bilginin yabancı dil öğretimindeki işlevi yadsınamaz. Bu temel kabulden hareketle Memiş'in (2016, s. 610) de ifade ettiği üzere yabancı dili öğrenen bir kişinin hedef dilde kültürel yeterlilik düzeyine erişebilmesi için o dilin konuşulduğu ülkenin coğrafî özelliklerini bilmesi, o toplum için önemli olan tarihî olaylar hakkında bilgi sahibi olması, hedef kültürdeki müziği, edebiyatı ve diğer sanatları tanıması, yemek, alışveriş, tanışma, doğum günü gibi durumlarda kullanılan kültürel kalıpları kullanabilmesi, günlük olaylarda uygun hareket etmesi ve o toplumda yaygın olan jest ve mimikleri bilmesi gerekmektedir.

Yabancı dil öğretiminde kültürel bilgide yetkinliğin öneminden hareketle yabancılara Türkçe öğretimiyle ilgilenen birçok araştırmacı da konuya farklı boyutlarda eğilmiştir. Öyle ki Türkiye'de, yabancılara Türkçe öğretiminde kültürün yeri ve işlevine dair hatırı sayılır derecede akademik yayın bulunmaktadır. Örneklendirmek gerekirse Demir ve Açık (2011) yabancılara Türkçe öğretiminde kültürlerarası yaklaşım ve metinlerde bulunması gereken özellikler üzerinde durmuş, Çangal (2012) yabanc1lara Türkçe öğretiminde kültürel bir öge olarak türkülerin nasıl değerlendirebileceğini irdelemiş, Demir (2014) yabancılara Türkçe öğretimi için hazırlanmış ders materyallerinden birini kültürel içerik açısından incelemiş ve son olarak Moralı ve Göçer (2019) uygulamalı bir araştırmada yabanc1lara Türkçe öğretiminde öğreticilerin kültür paylaşımına yönelik görüşlerini ele almıştır. Bu konudaki örnekleri arttırmak mümkündür.

Dilin doğal konuşurları için kaleme alınan edebî metinler, içerisinde çeşitli kültürel bilgileri barındırmaları açısından genelde yabancı dil özelde ise Türkçe öğretimi açısından özgün ders malzemesi niteliğindedir. Bu nitelik araştırmacıların da dikkatini çekmiştir ki tiyatro (Altaç, 2020) ve masal (Ayhan ve Aslan, 2014) gibi mensur türlerle şiir gibi (Demir Atalay, 2015) manzum türlerde kaleme alınan edebî eserlerin yabancılara Türkçe öğretiminde sürece nasıl dâhil edilebileceğine dair çalışmalar yapılmıştır. Dikkat çekici olan husus, Dede Korkut Hikâyeleri gibi kültürel açıdan oldukça değerli ancak klasik türdeki dil açısından günümüz Türkçesinden nispeten uzak bir metnin dahi birden çok araştırmacı tarafindan (Oğuztürk, 2019; Gürsoy Akyüz, 2020 ve YEE, 2021a) bu kapsamda değerlendirilmesidir. Dolayısıyla edebî metinler gerek uyarlama gerek uygun seviyede doğrudan getirme yoluyla kültürel bilgi paylaşımı açısından öğreticiye kolaylık sağlayacak birincil kaynaklardır. 
Kuşkusuz her edebî eser içerik açısından Türkçe öğretimi için uygun olmayabilir ancak Yunus Emre'nin bazı şiirleri ve ona ait birtakım menkıbeler orta ve ileri seviyede yabancılara Türkçe öğretimi için metne gerekli müdahaleler edilmek suretiyle kullanılabilir. Örneğin metin uyarlama teknikleriyle (sadeleştirme, eksiltme, özetleme, silme, ayrıntılandırma, değiştirme vb.) metin ders materyaline dönüştürebilir. Nitekim bu çerçevede örnek bir çalışma Yunus Emre Enstitüsü tarafından yapılmıştır. Türkçenin Sesi Yunus Emre Hikâyeleri (B1-B2) başlı̆̆ıyla hazırlanan eser, "Türkçeyi yabancı dil olarak öğrenen yetişkinlerin yardımcı okuma kitabı ihtiyacına cevap vermek amacıyla hazırlanmıştır. Türkçenin edebî söyleyişini hikâye türünün unsurlarıyla, büyük Anadolu mutasavvıfı Yunus Emre'nin hayatı ve düşüncesiyle birleştirerek üç farklı düzeye uyarlanan bu kitap, yardımcı okuma materyallerinde ilkleri bünyesinde barındırmaktadır." (YEE, 2021b). Bu türden ders materyallerinin sayısını arttırmak mümkündür çünkü Yunus Emre'nin şiir ve menkıbeleri hedef kitleye Türk kültürüne ilişkin bilgi paylaşımında bulunması açısından zengindir.

Türk kültüründeki birçok insanî değerin Yunus Emre'nin şiir ve menkıbelerinde kendini gösterdiği söylenebilir. Ancak bunların içinde en çok dikkat çekenlerden biri Yunus Emre'nin eserlerinde insana bakıştır. Yunus Emre, ötekileştirmeden bütün insanlığa sevgiyle yaklaştığı için çok kültürlü yabancı dil sınıflarında Yunus Emre'nin eserleri tematik açıdan kullanılmaya uygundur. Öğrenicilerin etnik, dinî ve sosyokültürel arka planları nedeniyle kültürlerarası çatışmaların doğabileceği sevgi, dostluk, kardeşlik, yardımlaşma, iyilik, barış gibi temaların yabancılara Türkçe öğretimi sürecinde işe koşulması yararlı olabilir. Nitekim Tatcı ve Erdoğan'ın da (2012, s. 77) söylediği gibi evrensel bir yaklaşımla bütün insanlığı; aşka, kardeşliğe, merhamet ve şefkate davet etmektedir. Eserleri incelendiğinde onun insan sevgisinin ve davetinin her türlü ayrımın üzerinde olduğu görülür. Çünkü "Yunus Emre insanı severken din, mezhep, 1rk ayrımı da gözetmez. Herkese aynı gözle bakar." (Sevgi, 2012, s. 101). Yunus Emre'nin bu bakışı, onun eserleri yüzyıllar boyunca Türk milleti tarafından sevilerek okunmuştur. Gölpınarlının (1971, s. 14) işaret ettiği üzere Türk edebiyatında bir yandan halka halkın diliyle hitap edişi, insani görüşü, beşerî duyuşu, insanı ve insanlığ́ kucaklaması diğer yandan buluşlarında, duyuşlarında tek sözle sanatındaki eşsizliği bakımından yüzyıllarca hüküm sürmüş, adını unutturmamıştır. Bugünse büsbütün benimsenmiş bir şairdir. Türk kültüründeki; hoşgörü, insana değer verme ve saygı duyma, insan ayrımı yapmama gibi önemli değerleri temsil eden Yunus Emre'nin eserleri içerik açısından çok kültürlü, muhtelif din, dil, mezhep ve kökenden öğrencilerin birlikte bulunduğu türdeş olmayan sınıflarda kullanıma elverişlidir ki çalışmanın bir sonraki bölümünde, bir Yunus Emre menkıbesi kültür paylaşımı çerçevesinde ders materyaline dönüştürülmüştür.

\subsection{Uygulama Örneği}

Çalışmanın bu bölümünde Yunus Emre'ye ait bir menkıbe ve şiir B1 seviyesinde kültürel bilgi paylaşımı çerçevesinde çalışma etkinliği olarak aşağıdaki gibi hazırlanmıştır.

\subsubsection{Yunus Emre'nin Sözü}

\section{Uygulanacak Dil Seviyesi: B1}

Öğrenme Alanı: Kültürel Paylaşım

Süre: 120 dakika

\section{Kazanımlar}

- Konuşmalara, uygun ifade kalıplarını kullanarak katılır.

- Bir tartışmaya uygun soru ve yönergelerle başkalarının katılımını sağlar.

- Aynı konuda yazılmış metinleri içerik açısından karşılaştırır.

- Görsellerle oluşturulmuş bir metindeki iletileri belirler.

- Okuduklarından hareketle çıkarımlarda bulunur.

- Okuduklarını özetler. 
- Karşılaştırmaya dayalı metinler yazar.

- Bir konuyla ilgili bilgi notları hazırlar.

Tablo 1. Örnek metin

\section{Altın ve Odun}

Bir gün Yunus dağda odun keserken karşıdan bir atlının gelmekte olduğunu gördü. Atlı, iyi giyimliydi. Süslü mücevherleri vardı. Yunus, bu atlının sultan olduğunu anladı. Sultan da Yunus'u görünce durdu ve sordu:

-Derviş burada ne yaparsın?

Yunus:

-Odun keserim, dedi. Sultan, Yunus'a bir miktar altın verdi.

Yunus:

-Sultanım bu nedir? Dedi.

Sultan da "Bu öyle bir şeydir ki nereye göndersen boş gelmez. Her ihtiyacını karşılar."

Yunus sordu:

-Ad1 nedir?

Sultan "Altındır." Dedi.

Yunus, öyle bir Allah kuluydu ki dağlara taşlara "Altın olun!” dese, altın olurdu. Bu duyguyu içinden geçirir geçirmez hemen o anda dağlar taşlar altın oldular. Yunus dedi ki:

-Sultanım, altın ne ki, neye yarar? Bunlar dünyalık şeylerdir. Taşa taş olmak, ağaca ağaç olmak yaraşır.

Böyle der demez altın olan taşlar, ağaçlar evvelki gibi oldular.

Kaynak: Özçelik, 2011, s. 33.

\section{Uygulama Aşamaları}

1. Öğretmen, sınıfa girer ve öğrencileri ile Yunus Emre hakkında konuşur. Yunus Emre'ye ait menkıbeyi (Altın ve Odun) okutur.

2. Menkıbede geçen bir ifade hakkında öğrencilere soru yöneltir: "Taşa taş olmak ağaca ağaç olmak yaraşır. ” Cümlesinden ne anliyorsunuz? Tartışınız.

3. Öğrencilerin fikir alışverişi yapmalarının ardından Yunus Emre'ye ait şiiri sınıfta dinletir. kimdir?"

4. Öğrencilere sorular yöneltir: "Şiirde Yunus Emre'nin "biz" olarak ifade ettiği

Tablo 2. Örnek șiir

Biz dünyadan gider olduk kalanlara selam olsun

Bizim için hayır dua kılanlara selam olsun

Ecel büke belimizi söyletmeye dilimizi

Hasta iken halimizi soranlara selam olsun

Tenim ortaya açıla yakasız gömlek biçile

Bizi bir arı vech ile yuyanlara selam olsun

Azrail alır canımız kurur damarda kanımız

Yayıcă̆ız kefenimiz saranlara selam olsun

Gider olduk dostumuza eremedik kasdımıza

Namaz için üstümüze duranlara selam olsun

Sözdür söylenir araya kimse döymez bu yaraya

İtip bizi makbereye koyanlara selam olsun

Bunda hep gelenler gider hergiz gelmez yola gider

Bizim halimizden haber soranlara selam olsun

Âşık oldur Hakk'ı seve Hak derdinde kıla deva

Bizim için hayır dua kılanlara selam olsun

Miskin Yunus söyler söyler sözü kan yaş ile doldu gözü

Bilmeyen ne bilsin bizi bilenlere selam olsun

Kaynak: Tatc1 ve Erdoğan, 2012, s. 139. 
Değerlendirme: Öğretmen kazanımlar çerçevesinde ve derste öğrenci katılımlarından da yola çıkarak Yunus Emre'nin dil özellikleri ve anlatım özellikleri hakkında bir değerlendirme yapar.

\section{Dil Becerilerini Geliştirmede Özgün Materyal Olarak Yunus Emre Şiir ve Menkıbeleri}

Genelde yabanc1 dil öğretimi özelde ise yabancılara Türkçe öğretiminde temel dil becerileri büyük oranda okuma ve dinleme metinleri aracılığılla geliştirilmektedir. İster yabancılara Türkçe öğretimi seti ders materyali olarak takip edilsin isterse de öğretici tarafından çalışma etkinlikleri hazırlansın metinler, dil becerilerini geliştirmede başat unsurlardır. Korkmaz'ın (2019, s. 124) da belirttiği gibi yabancılar Türkçe öğrenirken bu dilin; ses, şekil, cümle, yazım-noktalama ve dil bilgisi kurallarını bağlama uygun düşecek metinler aracılığıyla öğrenmektedir.

Metinler, özgün (otantik) olabileceği gibi öğreticiler tarafından yalnızca hedef kitleye belirli kelimeleri, kelime gruplarını ve dil bilgisi yapılarını öğretmek üzere kaleme alınmış yapay (kurmaca) metinler de olabilir. "Türkçe öğrenen yabancıların ana dili Türkçe olanlara göre hazırlanmış metinleri okuyup anlamaları güçtür. Ancak yabancılara Türkçe öğretiminde kullanmak için hazırlanmış Türkçe metin bulmak oldukça zordur. Türkçeyi yabancı dil olarak öğrenecekler için her seviyede Türkçe metin hazırlanmalıdır" (Sallabaş, 2012, s. 2217). Metin hazırlama işlemi, yeni bir metin oluşturma şeklinde ya da farklı amaçlarla oluşturulan kullanılabilecek metinleri yabancılara Türkçe öğretimi için uyarlama/değiştirme olabilir. Her iki yol da ek ya da yeni ders materyali hazırlamak için sık başvurulan yöntemlerdir.

Özgün (otantik) metin grubunda yer alan edebî metinler de yabancılara Türkçe öğretiminde kullanılmaktadır. Edebî metinlerin Türkçe öğretimi sürecine nasıl dâhil edilebileceği pek çok araştırmacının dikkatini çekmiş ve bu kapsamda teorik (Durmuş, 2013) ve uygulamalı çalışmalar ortaya konmuştur (Kaya, 2018). Konuya bu perspektiften bakıldığından bir yandan halk diğer yandan tekke/tasavvuf edebiyatının örnekleri arasında sayılabilecek edebî eserler veren Yunus Emre'ye ait şiir ve menkıbeler de doğrudan ya da uyarlama işleminden sonra yabancılara Türkçe öğretiminde beceri geliştirmek için ders materyali olarak kullanılmaya uygundur.

$\mathrm{Bu}$ iddianın çeşitli gerekçeleri bulunmaktadır. Öncelikle Yunus Emre şiirlerini yer yer Arapça ve Farsça gibi dillerden kelimeler de alarak halk diliyle yani konuşma diline yakın bir üslupla diğer bir deyiş̧le sade, açık, anlaşılır bir Türkçeyle oluşturmuştur. Bu sebeple yüzyıllar geçmesine karşın Yunus Emre şiirleri günümüz Türkçe okurları/konuşurları için kolaylıkla anlaşılmaktadır. Nitekim Gemalmaz (1991, s. 61) da "Çok kere, kelimeler ve kuruluşlar öylesine tabiî seçilmiştir ki şiirin Yunus Emre'ye ait olduğunu bilmesek günümüzün usta bir şairi tarafindan meydana getirilmiş olduğunu sanabiliriz. Yunus Emre'nin şiirlerinin çok söylenmiş, çok ezberlenmiş, çok istinsah edilmiş ve çok okunmuş ve okunmakta olmasının sebebi bu şiirlerin, konularından çok dilindeki bu doğallık olsa gerek" demektedir.

Yunus Emre'nin bulunduğu döneme göre şiirlerini sade bir Türkçeyle kaleme almas1, yabancı dil olarak Türkçe öğrenenlerin şiirleri anlamakta işini kolaylaştırmaktadır. Şiirlerde yer yer geçen Arapça ve Farsça kelimelerin ise Arap ve Fars dilli öğrencilere tanıdık geldiği söylenebilir. Gerçekten de saha gözlemleri, Türkiye'de Türk Dili ve Edebiyatı eğitimi alan yabancı öğrencilerin Yunus Emre'nin şiirlerini, döneminin ve sonrasının birçok şair ve yazarına göre daha kolay anladıklarını doğrulamaktadır. Bununla birlikte Yunus Emre'nin şiirlerinde kullandığ 1 Türkçenin kelime kadrosu ve gramatikal özelliklerin de zaman içerisinde değişmesi kuşkusuz günümüz Türkçesini öğrenen yabancılar için bir zorluk sayılmaktadır. Ancak bu zorluğu aşmak daha doğru bir ifadeyle hedef kitlenin bu metinleri okuduğu/dinlediği esnada bilişsel yükünü dil seviyesine uygun hâle getirmek için metin uyarlama tekniklerinden hareketle müdahaleler yapılabilir. Örneğin eskicil kelimeler, günümüzdeki karş1lıklarıyla yer değiştirilebilir ya da artık Türkçede kaybolmuş ekler metinden kaldırılabilir. Hâlihazırda pek 
çok edebî eser, uyarlama yoluyla yabancılara Türkçe öğretiminde kullanılmaktadır. Bu işlem sayesinde Yunus Emre'nin şiir ve menkıbeleri sadece kültürel bilgi paylaşımı için değil dil becerilerini geliştirmek için de kullanılabilir. Zira bu yöntemle yabancılara İngilizce öğretiminde hem modern hem de klasik İngiliz/Amerikan edebiyatına ait eserlerin seviyelendirilerek uzun yıllar öğretim materyali olarak kullanıldığı bilinmektedir.

\subsection{Uygulama Örneği}

Çalışmanın bu bölümünde Yunus Emre'ye ait bir menkıbe ve şiir B2 seviyesinde yabancılara Türkçe öğretiminde temel dil becerilerinin geliştirilmesi çerçevesinde çalışma etkinliği olarak aşağıdaki gibi hazırlanmıştır:

\subsubsection{Yunus Emre'yi Tantyalım}

\section{Uygulanacak Dil Seviyesi: B2}

Dil Becerileri: İletişimsel yöntem çerçevesinde ele alınan bu etkinlikte sınıf içi iletişimin artırılmasına yönelik olarak okuma, yazma, konuşma, dinleme becerilerinden yararlanılarak kültür unsurlarının öğretimine yer verilmiştir.

Süre: 120 dakika

\section{Kazanımlar}

- Soyut ve somut konular içeren metinlerin içeriğini ana hatlarıyla kavrayabilir.

- Kendisini ana dil konuşurlarıyla anlaşırken az çaba göstererek akıcı bir şekilde ifade edebilir.

- Bir konu hakkında görüş bildirebilir.

- Dinledikleri/izledikleri çerçevesinde ana düşünce ve yardımcı düşünceleri belirler.

- Mecazli ifadeleri belirler.

- Herhangi bir konuda eleştiri/yorum ve değerlendirme yapabilir.

- Kültürel bir öge/gelenek/etkinlik/mekân ile ilgili konuşmalara katılır.

Tablo 3. Örnek metin

\section{Dervişlerin Duası}

Yunus, Tabduk'a kırk yıl hizmet etti. Fakat kendisine ilahi âlemin sırlarından bir şey açılmamıştı. O da kaçıp dağlara, kırlara düştü. Bir gün bir mağarada dervişlere rastladı, onlarla arkadaş oldu. Her gece onlardan biri dua eder, duasının bereketiyle bir sofra yemek gelirdi. Sira Yunus'a geldi, o da dua etti:

-Ya Rabbim, benim yüzümü kara çıkarma. Onlar kimin hürmetine dua ediyorlarsa, onun hürmetine beni, utandırma! Dedi.

O gece iki sofra yemek geldi.

-Kimin yüzü suyu hürmetine dua ettin? Diye sordular.

Yunus:

-Önce siz söyleyin. Dedi.

Onlar:

-Biz, Tabduk Emre'nin kapısında kırk yıl hizmet eden Yunus diye bir ermiş vardır, onun hürmetine dua ederiz. Dediler.

Yunus bunu duyunca hemen Tabduk dergâhına geri döndü.

Kaynak: Özçelik, 2011, s. 45.

\section{Uygulama Aşamaları}

1. Öğretmen, sınıfa girer ve öğrencileri ile Yunus Emre hakkında konuşur. Tanıyıp tanımadıklarını sorar. Yunus Emre'ye ait menkıbeyi (Dervişlerin Duası) okutur.

2. Menkıbede geçen bir ifade hakkında öğrencilere soru yöneltir: "Can gövdeye konuktur, bir gün ola çıka gide kafesten kuş uçmuş gibi" ifadesi ne anlama gelmektedir?

3. Yunus Emre hakkında bilgisi olmayan öğrencileri için sınıfa kısa bir video götürür öğrencilerin etkinlik öncesinde konuşma becerisine ek olarak izleme-dinleme becerisi 
çerçevesinde de hazır olmalarını sağlar. Dersler çevrimiçi ise karekod paylaşarak dersin akışını sürdürür.

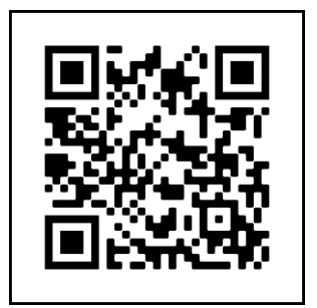

4. Videonun ardından Yunus Emre'nin yaşamı hakkında öğrencilerin düşüncelerini sorar.

5. Ardından Yunus Emre'ye ait şiiri (189-190) sınıfta tek tek her öğrenciye sesli okutur.

6. Öğrencilerin "yitmek" fiilinin manasını tartışmalarını sağlar ve öğrencilerin bu fiili farklı bağlamlarda cümle içinde kullanmalarını ister.

7. Son olarak genel bir soru yöneltir: "Okuduğunuz metinlerden hareketle Yunus Emre'nin özellikleri hakkında ne söyleyebilirsiniz?”

Tablo 4. Örnek şiir

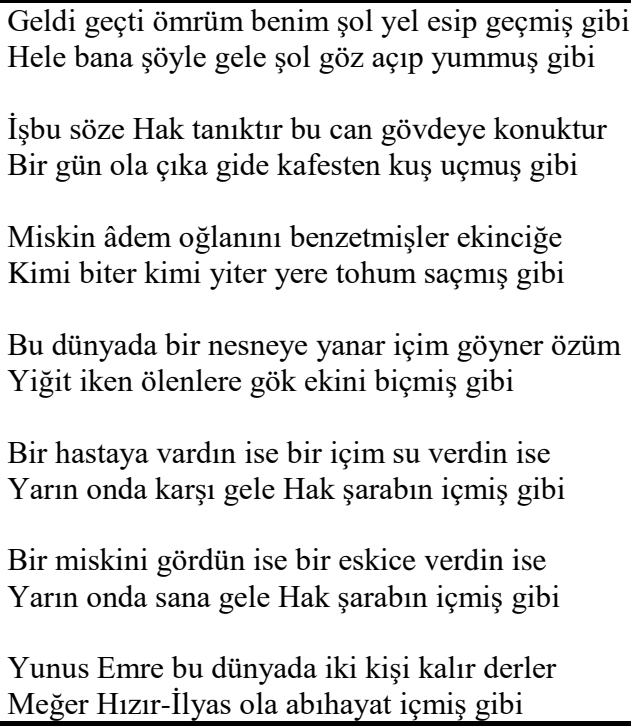

Kaynak: Tatc1 ve Erdoğan, 2012, s. 170.

Değerlendirme: Öğretmen kazanımlar çerçevesinde ve derste öğrenci katılımlarından da yola çıkarak Yunus Emre'nin yaşamı ve kültürümüzdeki önemi hakkında bir değerlendirme yapar.

\section{Sonuç ve Öneriler}

Türkçe, ikinci ve yabancı dil olarak gün geçtikçe artan bir ilgi görmektedir. Türkçeye karşı artan ilgiye paralel bir şekilde müstakil bir bilimsel disiplin olarak yabancılara Türkçe öğretimine yönelik akademik çalışmalar da artış kaydetmektedir. Bu akademik çalışmalar arasında, etkili iletişimin önemli bir bileşeni olan kültürel bilginin yabancilara Türkçe öğretiminde paylaşımına ve temel dil becerilerinin gelişimi için öğretim materyali hazırlamaya yönelik yayınlar önemli bir yer tutmaktadır. Edebî eserler, kültürel bilgiyi bağlama uygun ve doğal bir şekilde içermesi ve aynı zamanda özgün dil öğretim materyali niteliğinde olmasından dolayı bu iki başlıkta kullanılmaya elverişlidir. 
$\mathrm{Bu}$ çalışmada Türk edebiyatında yüz yıllardır ilgi gören Yunus Emre'nin şiir ve menkıbelerinden Türkçenin ikinci/yabancı dil olarak öğretiminde kültürel bilgi paylaşımı ve ders materyali olarak nasıl yararlanılabileceğinin üzerinde durulmuş ve amaca yönelik bazı uygulama örneklerine yer verilmiştir. İngilizce, Almanca, Fransızca ve Farsça gibi diğer dünya dillerinin öğretiminde edebî eserler çoğunlukla uyarlama yoluyla nasıl kullanılıyorsa benzer bir işlemin Yunus Emre'ye ait edebî eserlerde de kullanılabileceği gösterilmiştir. Son olarak yabancılara Türkçe öğretimi esnasında Yunus Emre'nin şiir ve menkıbelerinden yararlanmak isteyen öğretici ve araştırmacılar için aşağıdaki öneriler de sunulmaktadır:

- Yunus Emre menkıbeleri seviyelendirilerek hikâye setleri oluşturulabilir. Uygun menkıbelerin seçimi için menkıbeler, değerler eğitimi yaklaşımıyla incelenebilir.

- Yunus Emre menkıbelerinde kültürel ögeler tespit edilerek sadece bunlara dair çalışma etkinlikleri hazırlanabilir.

- Yunus Emre'nin bestelenmiş şiirlerine uygun çalışma etkinlikleri hazırlanarak bu şiirler dinleme metni olarak kullanılabilir.

- Tematik açıdan uygun Yunus Emre şiirleri, kelime kadrosu ve gramatikal açıdan sadeleştirerek okuma/yazma etkinliklerine dönüştürebilir.

- İyilik, doğruluk, insan sevgisi, aşk, gönül kırmama, mütevazılık gibi değerleri aktaran Yunus Emre şiirleri, kültürel bilgi paylaşımı için ders materyaline çevrilebilir.

\section{Kaynakça}

Akkaya, A. (2013). Yabancılara Türkçe öğretimi kapsamında fikralar: Nasreddin Hoca fikraları. Milli Folklor, (100), 171-181. Erişim adresi https://www.millifolklor.com/PdfViewer.aspx?Sayi=100\&Sayfa=168

Altaç, E. (2020). Edebi bir metin türü olarak tiyatronun yabancı dil olarak Türkçe öğretiminde kullanımı ve dört temel dil becerisine katkısı (Yayımlanmamış yüksek lisans tezi). Hacettepe Üniversitesi, Ankara.

Avrupa Konseyi Modern Diller Bölümü (2013). Diller için ortak öneriler çerçevesi. https://www.telc.net/fileadmin/user_upload/Publikationen/Diller_iain_Avrupa_Ortak_oneril er_AEeraevesi.pdf (Erişim tarihi: 28.07.2021).

Ayhan, M. S. ve Arslan, M. (2014). Edebî metin olarak masalların yabancılara Türkçe öğretiminde dilsel ve kişisel becerilerin gelişimine etkisi. Hitit Üniversitesi Sosyal Bilimler Enstitüsü Dergisi, 7(2), 543-559. https://doi.org/10.17218/husbed.25841

Barın, E. (2004). Yabancılara Türkçe öğretiminde ilkeler. Hacettepe Üniversitesi Türkiyat Araştırmaları Dergisi (HÜTAD), (1), 19-30. Erişim adresi https://dergipark.org.tr/tr/pub/turkiyat/issue/16660/329608

Binark, İ. ve Sefercioğlu, N. (1970). Yunus Emre hakkında bir bibliyografya denemesi. Ankara: Güven Matbaası.

Can, M. (2016). Yunus Emre bibliyografyası. Selçuk Üniversitesi Edebiyat Fakültesi Dergisi, (4), 301-319. Erişim adresi https://dergipark.org.tr/tr/pub/sefad/issue/16469/171863

Çangal, Ö. (2012). Yabancılara Türkçe öğretiminde kültür taşıyıcısı olarak türküler. Gazi Üniversitesi Türkçe Araştırmaları Akademik Öğrenci Dergisi, 2(2), 9-20. Erişim adresi https://www.researchgate.net/publication/322212130_Yabancilara_Turkce_Ogretiminde_Ku ltur_Tasiyicisi_Olarak_Turkuler

Demir A. ve Açık, F. (2011). Türkçenin yabancı dil olarak öğretiminde kültürlerarası yaklaşım ve seçilecek metinlerde bulunması gereken özellikler. TÜBAR, (30), 51-72. Erişim adresi https://dergipark.org.tr/tr/pub/tubar/issue/16971/177327 
Demir Atalay, T. (2015). Türkçenin yabancı dil olarak öğretiminde Safahat'tan hareketle atasözü öğretimi. Erzincan Üniversitesi Sosyal Bilimler Enstitüsü Dergisi, 9(2), 191-206. Erişim adresi https://dergipark.org.tr/tr/pub/erzisosbil/issue/45172/565554

Demir, D. (2014). Yabancı dil olarak Türkçe öğretimi kitaplarının kültürel içeriği. Hacettepe Üniversitesi Yabancı Dil Olarak Türkçe Araştırmaları Dergisi, (1), 53-61. Erişim adresi https://dergipark.org.tr/tr/pub/huydotad/issue/37783/436214

Durmuş, M. (2013). İkinci/yabancı dil öğretiminde/ediminde sadeleştirilmiş metin sorunları üzerine. Bilig, (60), 135-150. Erişim adresi https://www.acarindex.com/dosyalar/makale/acarindex-1423872979.pdf

Gemalmaz, E. (1991). Yunus Emre'nin şiirlerindeki dil özellikleri. Yunus Emre Sempozyumu Bildirileri, Atatürk Üniversitesi, Erzurum.

Gölpınarl1, A. (1971). Yunus Emre hayatı ve bütün şiirleri. İstanbul: Türkiye İş Bankası Kültür Yayınları.

Gürsoy Akyüz, S. (2019). Yabancı dil olarak Türkçe öğretiminde Dede Korkut Hikayeleri'nden yararlanılması (Yayımlanmamış yüksek lisans tezi). Hacettepe Üniversitesi, Ankara.

Kaya, M. (2014). Yunus Emre Divanı'nın Türkçe öğretimi açısından incelenmesi. Turkish Studies - International Periodical For The Languages, Literature and History of Turkish or Turkic, 9(12), 423-442. http://dx.doi.org/10.7827/TurkishStudies.7533

Kaya, M. (2018). Dokuzuncu Hariciye Koğuşu ve Yılkı Atı adlı eserlerin yabancılar için A2 düzeyine uyarlanması (Yayımlanmamış doktora tezi). Gazi Üniversitesi Eğitim Bilimleri Enstitüsü, Ankara.

Korkmaz, C. B. (2019). Yabancı dil olarak Türkçenin öğretiminde metin uyarlama. E. Boylu ve L. İltar (Ed), Yabancı dil olarak Türkçe ögretimi içinde (ss. 125-143). Ankara: Pegem Akademi.

Korkmaz, Z. (1973). Yunus Emre ve Anadolu Türkçesinin kuruluşundaki yeri. Türkoloji Dergisi. 5(1), 13-19. https://doi.org/10.1501/Trkol_0000000095

Memiş, M. R. (2016). Yabancı dil öğretiminde eğitim ortamı ve kültür aktarımı. Turkish Studies, 11(9), 605-616. http://dx.doi.org/10.7827/TurkishStudies.9506

Moralı, G. ve Göçer, A. (2019). Yabancı dil olarak Türkçe öğretiminde kültür paylaşımına yönelik öğretmen görüşleri. Ana Dili Eğitimi Dergisi, 7(4), 1115-1129. https://doi.org/10.16916/aded.609340

Oğuztürk, O. (2019). Tarihsel metinlerin yabancllara Türkçe öğretiminde materyal geliştirme açısından incelenmesi (Dede Korkut örneği) (Yayımlanmamış yüksek lisans tezi). İnönü Üniversitesi, Malatya.

Özçelik, M. (2011). Minyatürlerle Yunus Emre menkıbeleri. Ankara: Eskişehir Valiliği İl Kültür ve Turizm Müdürlüğü.

Sallabaş, M. E. (2012). Türkçeyi yabancı dil olarak öğrenenlerin konuşma kaygılarının $\begin{array}{llll}\text { değerlendirilmesi. Turkish } & \text { Studies, } & \text { 2200-2218. }\end{array}$ http://dx.doi.org/10.7827/TurkishStudies.3481

Sevgi, A. (2012). Yunus Emre'de insan sevgisinin evrensel niteliği üzerine. Turkish Studies, 7(1), 99-103. http://dx.doi.org/10.7827/TurkishStudies.3182

Tatc1, M. ve Erdoğan, A. (2012). Bizim Yunus. Ankara: Ankara Büyükşehir Belediye Başkanlığı Yayınları.

Tatc1, M. ve Gürelli, S. (1988). Yunus Emre bibliyografyast. Ankara: Kültür ve Turizm Bakanlığ 1 . 
Tezcan, S. (2012). Eski Anadolu Türkçesi ve Yunus Emre'nin şiirlerinin dili üzerine. A. Y. Ocak (Ed), Yunus Emre içinde (ss. 97-124). Ankara: T. C. Kültür ve Turizm Bakanlığı.

YEE. (2021a). Dede Korkut Hikâyeleri. https://www.yee.org.tr/tr/yayin/dede-korkut-hikayeleri (Erişim tarihi: 19.05.2021).

YEE. (2021b). Türkçenin Sesi Yunus Emre Hikâyeleri. https://www.yee.org.tr/tr/yayin/turkcenin-sesi-yunus-emre-hikayeleri-b1-b2, (Erişim tarihi: 19.05.2021).

\section{ETIKK ve BİLIMSEL İLKELER SORUMLULUK BEYANI}

$\mathrm{Bu}$ çalışmanın tüm hazırlanma süreçlerinde etik kurallara ve bilimsel atıf gösterme ilkelerine riayet edildiğini yazar(lar) beyan eder. Aksi bir durumun tespiti halinde Afyon Kocatepe Üniversitesi Sosyal Bilimler Dergisi'nin hiçbir sorumluluğu olmayıp, tüm sorumluluk makale yazarlarına aittir.

\section{ARAŞTIRMACILARIN MAKALEYE KATKI ORANI BEYANI}

1. yazar katkı oranı : $\% 100$ 